\title{
Molecular analysis of a consanguineous Iranian polycystic kidney disease family identifies a PKD2 mutation that aids diagnostics
}

\author{
Reza Vazifehmand ${ }^{1,2}$, Sandro Rossetti ${ }^{3}$, Sassan Saber ${ }^{4}$, Hamid Reza Khorram Khorshid ${ }^{5}$ and Peter C Harris ${ }^{3 *}$
}

\begin{abstract}
Background: Polycystic kidney diseases (PKD) are a group of monogenic disorders that are inherited dominantly (autosomal dominant PKD; ADPKD) or recessively, including, autosomal recessive PKD (ARPKD). A number of recessive, syndromic disorders also involve PKD but have a range of pleiotropic phenotypes beyond the kidney, and are enriched in consanguineous families.
\end{abstract}

Case presentation: We describe here a consanguineous Iranian pedigree in which PKD was diagnosed in four generations, but also included cases with additional abnormalities, including mental retardation. We employed molecular screening to reveal the etiology of the PKD. Since the PKD seemed to be dominantly inherited, molecular diagnostics was performed by direct sequencing of the ADPKD genes, PKD1 and PKD2. Clinical and imaging data was collected on family members. The sequence analysis revealed a PKD2 single base-pair deletion, c.1142delG, and segregation was demonstrated in 16 PKD patients from different branches of the family. In keeping with other reports, the PKD2 phenotype in this family was overall mild, and characterized by conserved kidney function, although 12 cases had some evidence of renal insufficiency. Several younger mutation carriers had borderline or no clinical characteristics of ADPKD, while a patient that required a renal transplant at $14 \mathrm{y}$ did not have the PKD2 mutation.

Conclusions: The molecular analysis of an Iranian family showed that the PKD was due to a PKD2 mutation. The identification of the causative mutation allowed an accurate diagnosis in a number of individuals with equivocal imaging data. Consequently, these patients could be followed appropriately as at-risk individuals. In addition, the PKD2 diagnosis ruled out a syndromic form of PKD as the cause of the additional phenotypes in the family.

Keywords: ADPKD, PKD2, Molecular diagnostics

\section{Background}

Polycystic kidney diseases (PKD) are a group of monogenic disorders characterized by cyst development in the kidney, but also often have extrarenal manifestations [1]. This group of disorders has been linked to defects in the functioning of primary cilia and therefore are termed ciliopathies [2]. The most common form of the disease (incidence 1/500-1000) is autosomal dominant PKD (ADPKD) that is typically a late onset disease characterized by progressive cyst development and often resulting

\footnotetext{
* Correspondence: harris.peter@mayo.edu

${ }^{3}$ Division of Nephrology and Hypertension, Mayo Clinic, 200 First Street SW, Rochester, MN 55905, USA

Full list of author information is available at the end of the article
}

in end-stage renal disease (ESRD) [3]. Clinically significant extrarenal manifestations include severe polycystic liver disease and an increased prevalence of intracranial aneurysms. ADPKD is genetically heterogeneous with two genes known, PKD1 and PKD2 [4,5]. PKD1 accounts for $\sim 85 \%$ of clinical cases and is associated with more severe disease, with ESRD at 54.3 y compared to $74 \mathrm{y}$ for PKD2 [6]. Recent data from Cornec-Le Gall also indicated a significance difference in age at ESRD between PKD1 cases with truncating compared to nontruncating mutations (55.6 y vs. 67.9 y, respectively) [7]. Diagnostics is usually possible by renal imaging with specific criteria determined for a positive diagnosis by ultrasound $[8,9]$, but molecular diagnostic screens can also be helpful to determine the gene involved and to

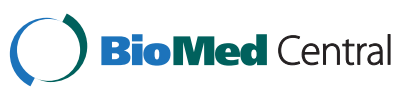


identify at-risk individuals $[10,11]$. In particular, knowing the gene and mutation type can be of prognostic value (see above), and in rare cases where there is interest, facilitate preimplantation genetic diagnostics.

The most common recessive form of PKD, autosomal recessive PKD (ARPKD; incidence 1:20,000), is most often a neonatal onset disorder and associated with significant neonatal demise; although adult presentation of the disease associated with at least one hypomorphic allele is increasingly recognized $[1,12,13]$. A number of other recessively inherited, syndromic forms of PKD have additional disease manifestations likely associated with ciliary dysfunction [2]. These diseases include the lethal Meckel syndrome, Joubert syndrome, Bardet Biedl syndrome and orofacial digital syndrome. Extrarenal manifestations range from liver, eye and digital defects to central nervous system abnormalities, including mental retardation. These rare disorders are enriched in consanguineous populations.

We describe here a complex Iranian family with multiple consanguineous relationships that manifests PKD, but also a number of other abnormalities, including heart defects, renal agenesis and mental retardation. Molecular testing of the ADPKD genes identified the molecular defect; highlighted variability associated with this mutation, and diagnosed at-risk individuals with negative or equivocal renal imaging data.

\section{Patients and methods}

The study was approved by the Ethics Committee at the Islamic Azad University (8888117001) and the Mayo Clinic IRB (285-00). Written informed consent was obtained from all patients for publication of this Case report. A copy of the written consent is available for review by the Editor of this journal. Clinical information was obtained by review of the clinical records and by interviewing the patients. Clinical data on kidney function (serum creatinine) and ultrasound imaging data to determine kidney size, number of cysts and the presence of renal stones was obtained for at-risk individuals, as available. The pedigree was drawn employing the Cyrillic program. Blood samples were collected from 25 family members for DNA isolation by standard salting out methods. The genomic DNA of the proband (V:16) was PCR amplified for all the coding exons of the PKD1 and PKD2 genes following previously published protocols [14-16]. Mutation analysis was performed by bidirectional sequencing on PCR-amplified products of all the coding exons for both the PKD1 and the PKD2 gene. Chromatograms were analyzed using the software Mutation Surveyor (SoftGenetics Inc.). Segregation analysis for the detected disease-associated mutation was performed in all available family members.

\section{Case presentation}

This family first came to our notice when the proband (V:16) underwent abdominal ultrasound analysis at $30 \mathrm{y}$ and a single, large cyst was detected in each kidney. Although these results did not meet the Ravine criteria for an ADPKD diagnosis, taking a family history revealed evidence of other family members with renal cystic disease (Table 1). Careful tracing of the family, plus renal ultrasound analysis and serum creatinine measurements, revealed a large family in which 125 individuals could be traced with at least 30 having some evidence of renal cystic disease, in four generations (Figure 1). The family had at least nine consanguineous couples, usually first cousins, and also cases with mental retardation, congenital heart disease renal agenesis and early onset ESRD. Although the consanguinity and range of extrarenal manifestations (some similar to those found in ciliopathies) suggested that recessive inheritance may be important, the PKD seemed to be inherited mainly in a dominant fashion. We, therefore, screened the ADPKD genes, $P K D 1$ and $P K D 2$, by sequence analysis for mutations in the proband. This screening revealed a PKD2 deletion, c.1142delG: p.G381fs71X as the only likely disease causing mutation (Figure 2). Segregation analysis in the subjects where DNA was available showed that 16 had the PKD2 mutation indicating that this is a PKD2 family. PKD2 is typically a much milder disease than PKD1 and this is reflected in this family where many individuals had rather few cysts and normal renal function (Table 1). Exceptions were IV:20 who had a renal transplant at 50 y and $\mathrm{V}: 1$ who started dialysis at $54 \mathrm{y}$. Other individuals with marked renal insufficiency were V:29 with an eGFR of $20 \mathrm{ml} / \mathrm{min} / 1.73 \mathrm{~m}^{2}$ at $54 \mathrm{y}$, $\mathrm{V}: 39$ with an eGFR of $31 \mathrm{ml} / \mathrm{min} / 1.73 \mathrm{~m}^{2}$ at 38 years and two older family members with eGFR of 27 (IV:10) and $39 \mathrm{ml} / \mathrm{min} / 1.73 \mathrm{~m}^{2}$ (IV:17) at $75 \mathrm{y}$ and $63 \mathrm{y}$, respectively. Several younger individuals shown to inherit the PKD2 mutation had cyst numbers below the threshold for diagnosis by ultrasound and in at least one case at 20y (VI:30) no renal or hepatic cysts were detected. Kidney stones were commonly found in affected cases and are a known complication of ADPKD.

A risk in such a consanguineous family is that both parents will be affected in which case one in four of their pregnancies would be homozygous for the PKD2 mutation. $P k d 2^{-/-}$mice are embryonic lethal, dying by $14.5 \mathrm{~d}$ of gestation, and it is assumed in humans, but never proven, that having two fully penetrant PKD2 mutations is incompatible with life. To further determine the significance of the PKD2 mutation in this family, we analyzed a number of family members with unusual manifestations, including kidney agenesis, early onset ESRD or other extra-renal manifestations sometimes related with syndromic PKD, to see if the PKD2 mutant 
Table 1 Clinical details of affected cases and others with unusual phenotypes

\begin{tabular}{|c|c|c|c|c|c|c|c|c|c|}
\hline \multirow[t]{2}{*}{ Patient No. } & \multirow[t]{2}{*}{ Sex } & \multirow[t]{2}{*}{$\begin{array}{l}\text { Age } \\
(y)+\end{array}$} & \multirow{2}{*}{$\begin{array}{c}\text { Renal } \\
\text { Function } \\
\text { (Serum } \\
\text { Creatinine; } \\
\text { mg/dl) }\end{array}$} & \multicolumn{2}{|c|}{$\begin{array}{l}\text { Kidney Length^ } \\
(\mathrm{mm})\end{array}$} & \multicolumn{2}{|c|}{$\begin{array}{c}\text { Notable Kidney Features from } \\
\text { Imaging* }\end{array}$} & \multirow[t]{2}{*}{ Other Findings } & \multirow[t]{2}{*}{$\begin{array}{l}\text { Genetic } \\
\text { results }\end{array}$} \\
\hline & & & & Right & Left & Right & Left & & \\
\hline \multicolumn{10}{|l|}{ Affected } \\
\hline$\|1\|: 4$ & $\mathrm{~F}$ & 56 & N/A & N/A & N/A & N/A & N/A & Dead; PKD & $\mathrm{N} / \mathrm{D}$ \\
\hline$\|1\|: 8$ & M & 63 & N/A & N/A & N/A & N/A & N/A & Dead; PKD & N/D \\
\hline IV:9 & $F$ & 67 & 1.4 & 113 & 125 & LC 10x6 mm & Normal & & 1142delG \\
\hline IV:10 & $\mathrm{F}$ & 75 & 1.8 & 108 & 135 & Multiple cysts & $9 \mathrm{~mm}$ stone & & 1142delG \\
\hline IV:13 & M & 77 & $\begin{array}{l}\text { Dialysis } \\
(75 \mathrm{y})\end{array}$ & 105 & 100 & LC $22 \times 10 \mathrm{~mm}$ & $\begin{array}{l}11 \mathrm{~mm} \text { stone in } \\
\text { middle caulis }\end{array}$ & Dead; PKD & N/D \\
\hline IV:17 & $M$ & 63 & 1.8 & 118 & 110 & LC $15 \times 8 \mathrm{~mm}$ & $9 \mathrm{~mm}$ stone & & 1142delG \\
\hline IV:20 & $\mathrm{F}$ & 53 & $\operatorname{Tx}(50 y)$ & 150 & 160 & Multiple cysts & Multiple cysts & Dead; PKD & N/D \\
\hline IV:23 & M & 50 & 0.9 & 115 & 105 & $4 \mathrm{~mm}$ stone & LC $15 \times 8 \mathrm{~mm}$ & & N/D \\
\hline$\vee: 1$ & M & 54 & $\begin{array}{l}\text { Dialysis } \\
(54 \mathrm{y})\end{array}$ & N/A & N/A & N/A & N/A & Dead; PKD & $N / D$ \\
\hline$V: 5$ & M & 42 & 1.1 & 125 & 110 & LC $15 \times 8 \mathrm{~mm}$ & $3 \mathrm{~mm}$ stone & & 1142delG \\
\hline & & & & & & $\begin{array}{l}2 \mathrm{~mm} \text { stone in } \\
\text { middle caulis }\end{array}$ & & & \\
\hline $\mathrm{V}: 9$ & $\mathrm{~F}$ & 38 & 1.3 & 100 & 95 & LC 23×18 mm & $9 \mathrm{~mm}$ stone in & & 1142delG \\
\hline & & & & & & $\begin{array}{l}3.5 \mathrm{~mm} \text { stone in } \\
\text { middle caulis }\end{array}$ & & & \\
\hline$V: 14$ & M & 32 & 0.9 & 105 & 105 & Multiple cysts & Stone $3 \mathrm{~mm}$ & & 1142delG \\
\hline V:16 (proband) & $M$ & 30 & 1.2 & 105 & 100 & 1 cyst, $12 \times 12$ mm & 1 cyst, $27 \times 22$ mm & & 1142delG \\
\hline$V: 22$ & M & 46 & 1.2 & 118 & 110 & $3 \mathrm{~mm}$ stone & 1 cyst, $13 \times 13$ mm & & 1142delG \\
\hline$V: 24$ & M & 35 & 0.9 & 105 & 107 & Normal & $2 \mathrm{~mm}$ stone & & 1142delG \\
\hline \multirow[t]{2}{*}{$\mathrm{V}: 27$} & $\mathrm{~F}$ & 49 & 1.3 & 108 & 115 & Normal & $3.5 \mathrm{~mm}$ stone & & 1142delG \\
\hline & & & & & & & LC $3 \times 3 \mathrm{~mm}$ & & \\
\hline \multirow[t]{2}{*}{$V: 29$} & $\mathrm{~F}$ & 54 & 2.5 & 105 & 110 & 1 cyst $10 x 10$ mm & 1 cyst, $8 \times 8$ mm & 1 liver cyst & 1142delG \\
\hline & & & & & & & $3 \mathrm{~mm}$ stone & & \\
\hline \multirow[t]{2}{*}{$V: 39$} & F & 38 & 1.8 & 160 & 170 & Multiple cysts & Multiple cysts & & 1142delG \\
\hline & & & & & & & $\begin{array}{l}4.5 \mathrm{~mm} \text { stone in } \\
\text { interlobular region }\end{array}$ & & \\
\hline$V: 43$ & $\mathrm{~F}$ & 37 & 0.7 & 112 & 124 & Normal & 1 cyst, $13 \times 13$ mm & $22 \times 23 \mathrm{~mm}$ liver cyst & 1142delG \\
\hline Vl:5 & $F$ & 20 & 0.7 & 95 & 90 & $1.5 \mathrm{~mm}$ stone & Normal & & 1142delG \\
\hline Vl:6 & $\mathrm{F}$ & 16 & 0.7 & 108 & 109 & Normal & $3 \mathrm{~mm}$ stone & & 1142delG \\
\hline Vl:30 & $\mathrm{F}$ & 16 & 0.8 & 108 & 98 & Normal & Normal & & 1142delG \\
\hline \multicolumn{10}{|l|}{$\begin{array}{l}\text { PKD suspected } \\
\text { but not proven }\end{array}$} \\
\hline \multirow[t]{2}{*}{ IV:15 } & \multirow[t]{2}{*}{ M } & \multirow[t]{2}{*}{62} & \multirow[t]{2}{*}{0.8} & \multirow[t]{2}{*}{105} & \multirow[t]{2}{*}{100} & LC $20 \times 10 \mathrm{~mm}$ & \multirow{2}{*}{$\begin{array}{l}9 \mathrm{~mm} \text { stone in } \\
\text { middle caulis }\end{array}$} & & \multirow[t]{2}{*}{ N/D } \\
\hline & & & & & & $\begin{array}{l}3.5 \mathrm{~mm} \text { stone in } \\
\text { middle caulis }\end{array}$ & & & \\
\hline IV:19 & $\mathrm{F}$ & 51 & 1.5 & 108 & 105 & $\begin{array}{c}1 \text { cyst, } \\
12 \times 8 \mathrm{~mm} ; 10 \mathrm{~mm} \\
\text { stone }\end{array}$ & $\begin{array}{l}11 \mathrm{~mm} \text { stone in } \\
\text { middle caulis }\end{array}$ & & $N / D$ \\
\hline $\mathrm{V}: 10$ & $\mathrm{~F}$ & 41 & 1.2 & 108 & 105 & 1 cyst, $10 \times 5$ mm & Normal & & N/D \\
\hline $\mathrm{V}: 19$ & M & 40 & 1.1 & 112 & 108 & 1 cyst, $6 \times 6$ mm & Normal & & $N / D$ \\
\hline$V: 25$ & $M$ & 32 & 0.8 & 100 & 105 & 1 cyst, $6 \times 6$ mm & Normal & & $\mathrm{N} / \mathrm{D}$ \\
\hline$V: 26$ & $M$ & 26 & 0.8 & 105 & 100 & $2 \mathrm{~mm}$ stone & $1 \mathrm{~mm}$ stone & & $\mathrm{N} / \mathrm{D}$ \\
\hline
\end{tabular}


Table 1 Clinical details of affected cases and others with unusual phenotypes (Continued)

\begin{tabular}{|c|c|c|c|c|c|c|c|c|c|}
\hline \multirow[t]{2}{*}{ Patient No. } & \multirow[t]{2}{*}{ Sex } & \multirow[t]{2}{*}{$\begin{array}{l}\text { Age } \\
(y)+\end{array}$} & \multirow{2}{*}{$\begin{array}{c}\text { Renal } \\
\text { Function } \\
\text { (Serum } \\
\text { Creatinine; } \\
\text { mg/dl) }\end{array}$} & \multicolumn{2}{|c|}{$\begin{array}{l}\text { Kidney Length^ } \\
(\mathrm{mm})\end{array}$} & \multicolumn{2}{|c|}{$\begin{array}{c}\text { Notable Kidney Features from } \\
\text { Imaging* }\end{array}$} & \multirow[t]{2}{*}{ Other Findings } & \multirow[t]{2}{*}{$\begin{array}{l}\text { Geneti } \\
\text { results }\end{array}$} \\
\hline & & & & Right & Left & Right & Left & & \\
\hline $\mathrm{VI}: 2$ & $\mathrm{~F}$ & 14 & 0.8 & 95 & 107 & Normal & $\begin{array}{l}1 \text { cyst, } 5 \times 4 \mathrm{~mm} ; \\
1.5 \mathrm{~mm} \text { stone }\end{array}$ & & $\mathrm{N} / \mathrm{D}$ \\
\hline Vl:14 & M & 24 & 1.3 & 107 & 105 & $2 \mathrm{~mm}$ stone & 1 cyst, $7 \times 6$ mm & & $N / D$ \\
\hline VI:16 & M & 24 & 1.7 & 110 & 112 & Normal & 1 cyst, 8X10 mm & & $N / D$ \\
\hline VI:17 & $\mathrm{F}$ & 17 & 0.8 & 95 & 95 & 1 stone & Normal & & $N / D$ \\
\hline Vl:22 & M & 45 & 1.4 & 107 & 105 & 1 cyst, $8 \times 5 \mathrm{~mm}$ & $2.6 \mathrm{~mm}$ stone & & N/D \\
\hline VI:24 & M & 33 & 1.1 & 112 & 100 & 1 cyst, 6 mm & Normal & & $N / D$ \\
\hline \multicolumn{10}{|l|}{ Unaffected } \\
\hline$V: 3$ & $\mathrm{~F}$ & 53 & 0.9 & 105 & - & Normal & Congenitally absent & & $1142 \mathrm{G}$ \\
\hline$V: 17$ & M & 39 & 0.9 & 110 & 100 & Normal & Normal & & $N / D$ \\
\hline$V: 32$ & $\mathrm{~F}$ & 64 & 3.59 & 100 & 95 & $\begin{array}{l}43 \mathrm{~mm} \text { stone, } \\
\text { hydronephrosis }\end{array}$ & $6.7 \mathrm{~mm}$ stone & & $1142 \mathrm{G}$ \\
\hline \multirow[t]{2}{*}{ VI:9 } & $\mathrm{F}$ & 20 & 0.7 & 100 & 96 & Normal & Normal & $\begin{array}{l}\text { Non Syndromic Mental } \\
\text { Retardation, }\end{array}$ & $N / D$ \\
\hline & & & & & & & & Normal Karyotype & \\
\hline \multirow[t]{2}{*}{ VI:10 } & M & 16 & 0.7 & 108 & 109 & Normal & Normal & $\begin{array}{l}\text { Non Syndromic Mental } \\
\text { Retardation }\end{array}$ & $N / D$ \\
\hline & & & & & & & & Normal Karyotype & \\
\hline Vl:19 & $\mathrm{F}$ & 34 & 0.8 & 95 & 105 & Normal & Normal & & $1142 \mathrm{G}$ \\
\hline Vl:20 & M & 46 & 0.7 & 100 & 105 & Normal & Normal & & $1142 \mathrm{G}$ \\
\hline Vl:28 & M & $?$ & N/A & N/A & N/A & N/A & N/A & $\begin{array}{l}\text { Congenital heart disease, } \\
\text { Down syndrome; Dead }\end{array}$ & N/D \\
\hline VIll:3 & M & 17 & Tx (14y) & 85 & - & No cysts & Congenitally absent & Reflux Nephropathy & $1142 \mathrm{G}$ \\
\hline
\end{tabular}

${ }^{*} L C$, largest cyst; $\wedge N / E$, not enlarged; $N / D$, not determined; $N / A$, not available; $+=$ age last imaging data available.

allele could be playing a role. IV:17 is affected and second cousin to his partner (V:3), who had just a single kidney, but genetic analysis showed she did not have the PKD2 mutation. V:40 is married to his affected first cousin (V:39) and they had two children who died at a young age (one with Down syndrome and congenital heart disease), but again the father did not have the PKD2 mutation. VII:3 had a solitary kidney and ESRD requiring a renal transplant at $14 y$, although no cysts were detected. His maternal grandmother (V:29) had renal insufficiency due to PKD (Table 1) and large kidney stones and the paternal grandmother (V:32) had kidney stones and hydronephrosis. However, genetic analysis showed that neither of his parents (VI:19 nor VI:20) or the paternal grandmother had the PKD2 mutation, and so the renal failure was not PKD related and most likely due to reflux nephropathy. The two sibs with mental retardation (VI:9 and VI:10) are at risk for PKD2 as the father is affected, but neither had evidence of cysts at $20 \mathrm{y}$ and 16y, respectively. Unfortunately, no samples were available to test if they had the PKD2 mutation.

\section{Conclusions}

We describe here an Iranian family with multiple consanguinity loops with over 30 individuals with PKD. Despite the complex structure of the family, by molecular testing we have been able to show that the PKD is due to a truncating mutation to PKD2. This firm diagnosis rules out that syndromic forms of PKD that are enriched in consanguineous populations are playing a role and showed that renal failure in one child was not related to the PKD2 mutation.

Considerable phenotypic variability was seen in the family both in terms of renal survival, kidney dimensions and the occurrence of kidney stones. However, it is well document that there can be considerable intra-familial variability in $A D P K D$, indicating that other genetic and environmental factors significantly influence the phenotype [17].

Renal ultrasound and other imaging methods are a reasonably reliable method to diagnose ADPKD in atrisk adults. However, ultrasound is less reliable in the milder PKD2, especially in younger individuals, as illustrated in this family with several cases with equivocal imaging data, showing even with the recent ultrasound 


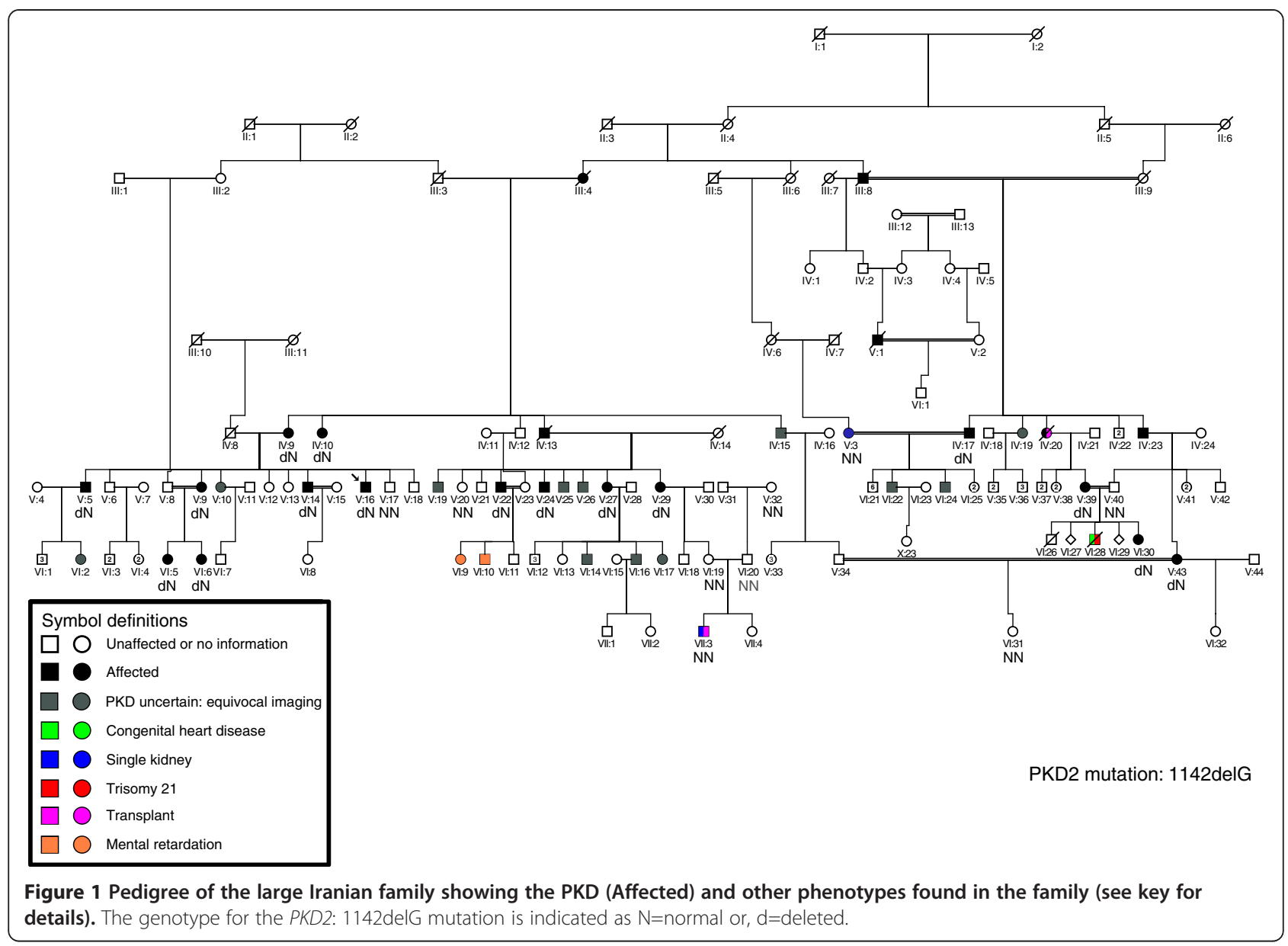

criteria that there is a significant false negative rate, especially when state-of-the-art ultrasound equipment is not employed $[8,18]$. Molecular diagnostics in ADPKD requires some considerable effort because of the involvement of the large and complex PKD1 gene, as well as $P K D 2$, and because of the high level of allelic heterogeneity meaning that both genes need to be fully sequenced to identify the disease gene $[10,19]$. Commercial testing is therefore expensive. However, this family illustrates the useful role for molecular diagnostics in ADPKD. PKD2 was identified as the disease, and once the disease mutation has been detected the rest of the family can be readily and inexpensively screened, with unequivocal diagnostic data obtained. In this family, this has helped resolve the etiology in some patients with unusual phenotypes and identified those at risk for developing

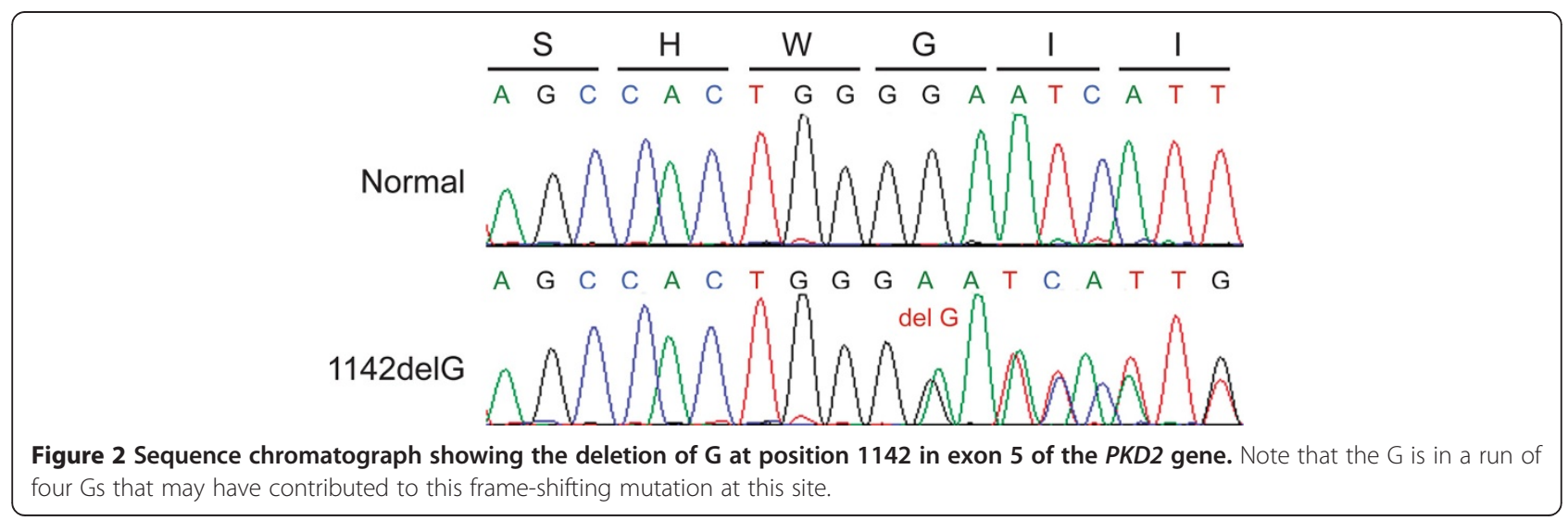


ADPKD even if no clinical signs are yet present. This means precious resources can be concentrated on following these individuals, with prompt treatment of hypertension, urinary tract infections, kidney stones and other complications [11]; and not those unaffected. Although molecular diagnostic is not required in every suspected ADPKD family it does have a valuable part to play in some complex families.

\section{Abbreviations}

PKD: Polycystic kidney disease; ADPKD: Autosomal dominant PKD; ARPKD: Autosomal recessive PKD; ESRD: End-stage renal disease; LRPCR: Long range PCR.

\section{Competing interests}

The authors declare that they have no competing interests.

\section{Authors' contributions}

RV conceived the study, collected DNA samples and clinical data and helped write the paper; SR did the molecular studies and helped write the paper; SS collected the biochemical information and edited the paper; HRKK helped collect the clinical data and edited the paper; and PCH oversaw the study and prepared the final draft of the paper. All authors read and approved the final manuscript.

\section{Acknowledgments}

We wish to thank all the family members and clinicians who participated in this study. This work was supported by NIDDK grant DK058816 and the Mayo Clinic PKD Translational Center (DK090728).

\section{Author details}

'Department of Molecular Pathology, Massoud Laboratory, Tehran, Iran. ${ }^{2}$ Young Researchers Club, Islamic Azad University, Rasht, Iran. ${ }^{3}$ Division of Nephrology and Hypertension, Mayo Clinic, 200 First Street SW, Rochester, MN 55905, USA. ${ }^{4}$ Department of Internal Medicine, Shariati Hospital, Tehran University of Medical Sciences, Tehran, Iran. ${ }^{5}$ Genetic Research Centre, University of Social Welfare and Rehabilitation Sciences, Tehran, Iran.

Received: 24 May 2013 Accepted: 4 September 2013 Published: 8 September 2013

\section{References}

1. Harris PC, Torres VE: Polycystic kidney disease. Annu Rev Med 2009, 60:321-337.

2. Fliegauf $M$, Benzing $T$, Omran $H$ : When cilia go bad: cilia defects and ciliopathies. Nat Rev Mol Cell Biol 2007, 8:880-893.

3. Torres VE, Harris PC, Pirson Y: Autosomal dominant polycystic kidney disease. Lancet 2007, 369:1287-1301.

4. European Polycystic Kidney Disease Consortium: The polycystic kidney disease 1 gene encodes a $14 \mathrm{~kb}$ transcript and lies within a duplicated region on chromosome 16. Cell 1994, 77:881-894.

5. Mochizuki T, Wu G, Hayashi T, Xenophontos SL, Veldhusien B, Saris JJ, Reynolds DM, Cai Y, Gabow PA, Pierides A, Kimberling WJ, Breuning MH, Deltas CC, Peters DJM, Somlo S: Pkd2, a gene for polycystic kidney disease that encodes an integral membrane protein. Science 1996, 272:1339-1342.

6. Hateboer N, van Dijk MA, Bogdanova N, Coto E, Saggar-Malik AK, San Millan J, Torra R, Breuning M, Ravine D: Comparison of phenotypes of polycystic kidney disease types 1 and 2. Lancet 1999, 353:103-107.

7. Cornec-Le Gall E, Audrezet MP, Chen JM, Hourmant M, Morin MP, Perrichot R, Charasse C, Whebe B, Renaudineau E, Jousset P, Guillodo MP, Grall-Jezequel A, Saliou P, Ferec C, Le Meur Y: Type of PKD1 mutation influences renal outcome in ADPKD. J Am Soc Nephrol 2013, 24:1006-1013.

8. Pei Y, Obaji J, Dupuis A, Paterson AD, Magistroni R, Dicks E, Parfrey P Cramer B, Coto E, Torra R, San Millan JL, Gibson R, Breuning M, Peters D, Ravine D: Unified criteria for ultrasonographic diagnosis of adpkd. J Am Soc Nephrol 2009, 20:205-212.
9. Ravine D, Gibson RN, Walker RG, Sheffield L, Kincaid-Smith P, Danks DM: Evaluation of ultrasonographic diagnostic criteria for autosomal dominant polycystic kidney disease 1. Lancet 1994, 343:824-827.

10. Harris P, Rossetti S: Molecular diagnostics of autosomal dominant polycystic kidney disease (adpkd). Nat Rev Nephrol 2010, 6:197-206.

11. Harris PC, Torres VE: Polycystic kidney disease, autosomal dominant: GeneReviews at GeneTests. University of Washginton, Seattle: Medical Genetics Information Resource [database online] Copyright; 1993. 1997-2008, http://www.genetests.org.

12. Adeva M, El-Youssef M, Rossetti S, Kamath PS, Kubly V, Consugar M, Milliner DS, King BF, Torres VE, Harris PC: Clinical and molecular characterization defines a broadened spectrum of autosomal recessive polycystic kidney disease(adpkd). Medicine (Baltimore) 2006, 85:1-21.

13. Bergmann C, Senderek J, Sedlacek B, Pegiazoglou I, Puglia P, Eggermann T, Rudnik-Schneborn S, Furu L, Onuchic LF, De Baca M, Germino GG, GuayWoodford L, Somlo S, Moser M, Buttner R, Zerres K: Spectrum of mutations in the gene for autosomal recessive polycystic kidney disease (arpkd/ pkhd1). J Am Soc Nephrol 2003, 14:76-89.

14. Rossetti S, Consugar MB, Chapman AB, Torres VE, Guay-Woodford LM, Grantham JJ, Bennett WM, Meyers CM, Walker DL, Bae K, Zhang QJ, Thompson PA, Miller JP, Harris PC, Consortium C: Comprehensive molecular diagnostics in autosomal dominant polycystic kidney disease. J Am Soc Nephrol 2007, 18:2143-2160.

15. Rossetti S, Kubly VJ, Consugar MB, Hopp K, Roy S, Horsley SW, Chauveau D, Rees L, Barratt TM, van't Hoff WG, Niaudet WP, Torres VE, Harris PC: Incompletely penetrant pkd1 alleles suggest a role for gene dosage in cyst initiation in polycystic kidney disease. Kidney Int 2009, 75:848-855.

16. Rossetti S, Strmecki L, Gamble V, Burton S, Sneddon V, Peral B, Roy S, Bakkaloglu A, Komel R, Winearls CG, Harris PC: Mutation analysis of the entire pkd1 gene: Genetic and diagnostic implications. Am J Hum Genet 2001, 68:46-63.

17. Harris PC, Rossetti S: Determinants of renal disease variability in adpkd. Adv Chronic Kidney Dis 2010, 17:131-139.

18. Huang E, Samaniego-Picota M, McCune T, Melancon JK, Montgomery RA, Ugarte R, Kraus E, Womer K, Rabb H, Watnick T: DNA testing for live kidney donors at risk for autosomal dominant polycystic kidney disease. Transplantation 2009, 87:133-137.

19. Rossetti S, Harris PC: Genotype-phenotype correlations in autosomal dominant and autosomal recessive polycystic kidney disease. J Am Soc Nephrol 2007, 18:1374-1380.

doi:10.1186/1471-2369-14-190

Cite this article as: Vazifehmand et al:: Molecular analysis of a consanguineous Iranian polycystic kidney disease family identifies a PKD2 mutation that aids diagnostics. BMC Nephrology 2013 14:190.

\section{Submit your next manuscript to BioMed Central and take full advantage of:}

- Convenient online submission

- Thorough peer review

- No space constraints or color figure charges

- Immediate publication on acceptance

- Inclusion in PubMed, CAS, Scopus and Google Scholar

- Research which is freely available for redistribution 